\title{
Smartphone-Based Virtual Reality as an Immersive Tool for Teaching Marketing Concepts
}

Haithem Zourrig, Kent State University at Stark, USA

\begin{abstract}
With the advent of virtual reality (VR) technology and the ubiquity of mobile devices, smartphonebased VR has become more affordable and accessible to business educators and millennial students. While millennials expect learning to be fun and prefer working with current technology, educators are constantly challenged to integrate new technology into the curriculum and evaluate the learning outcomes. This study examines the gain in learning effectiveness and students' intrinsic motivations that would result from the use of VR as compared to the use of traditional learning activity, namely think-pair and share. The results show that students who took part in the VR simulation demonstrated a better understanding of concepts and reported a better learning experience as compared to those who participated in the think-pair-share activity. In particular, the findings show evidence of higher intrinsic motivation and better learning outcomes.
\end{abstract}

\section{KEYWORDS}

Immersion, Intrinsic Motivation, Learning Effectiveness, Marketing Education, Virtual Reality

\section{INTRODUCTION}

Virtual reality (VR) refers to immersive, interactive, multisensory, viewer-centered, three-dimensional computer-generated environment (Mandal, 2013; Toshniwal \& Dastidar, 2014). Though VR was first introduced to target entertainment and gaming, recent studies have shown its potential use for educational purposes (see Choi et al., 2016 for review). With the advent of smartphone devices and free VR apps available for download (e.g., Google apps and Apple stores), VR technology has become more affordable and accessible than what it used to be a few years ago. For instance, students can use their smartphones (androids or iOS) to download free apps and slide them into the cardboard.

In fact, there is a great potential in using smartphone-based VR as a teaching tool that would complement and improve the teaching effectiveness and the overall students' learning experience (Jensen \& Konradsen, 2018). In particular, many studies in management education have reported opportunities for using VR in teaching retailing principles (Drake-Bridges et al., 2011), social marketing (Dietrich et al., 2019), tourism marketing (Hassan \& Jung, 2018), and brand management (Belei et al., 2011).

One of the most important courses in the marketing curriculum is marketing research. For many instructors, teaching marketing research depends heavily on concepts drawn from consumer behavior 
(Bridges, 2020). While many students recognize the psychological complexities of consumer behavior, they often find it challenging to integrate the learned concepts into a coherent framework that facilitates learning (Lincoln, 2016). For instance, the concepts of hedonic shopping (i.e., the enjoyment and pleasure that consumers may experience while shopping), psychological time (i.e., the sense of the passage of time when purchasing a product), and the flow state (i.e., the sense of playfulness and distorted sense of time) are experiential by nature. They would be better taught if they are integrated within a comprehensive framework related to the consumer's shopping experience. As VR enables simulating shopping experiences, the relevance of VR to teach these concepts becomes instrumental.

Hence, the purpose of this paper is to highlight some merits of using smartphone-based VR to teach marketing concepts. This article reports on the results of a VR simulation activity used in a marketing research class to teach students a few consumer behavior (CB) concepts before setting up experimentations.

The paper is organized as follows. First, the opportunity of using smartphone-based VR as an immersive teaching tool is highlighted. Second, the paper explains how the proposed VR innovation relates to the marketing curriculum objectives. The paper also describes the VR simulation and positions its novelty with regard to learning taxonomies. Thereafter, the paper reports some findings from assessing the VR effectiveness and conclude with some challenges and the potential adaptability of the VR simulation to other marketing courses.

\section{BACKGROUND}

\section{Learning Opportunities with VR}

Marketing educators have been using a variety of learning activities to teach students marketing concepts. These include experiential projects (Morgan \& McCabe, 2012; Titus \& Petroshius, 1993), computer-based simulations (Carter, 2002), self-photography projects (Hartman \& Braunstein, 1998), active-learning assignments (Lawson, 1995), and videography (Smith \& Fisher 2006), to name a few.

While these activities foster active learning, the increasing interest in virtual reality (VR) among students provides a compelling reason to incorporate VR into the marketing curriculum. In particular, millennials are technologically literate, being immersed in a variety of emerging technologies since their birth, they often quote traditional teaching and learning environments as boring (Mangold, 2007).

As nowadays students are looking for immersive learning experiences, it is not surprising to find millennials embracing VR. Indeed, a survey conducted by Touchstone Research in 2015 points to the same conclusion: $73 \%$ of millennials are highly interested in VR. In the same vein, many businesses and particularly retailers (e.g., Lowes, Walmart), have been working on integrating VR into their marketing activities, to improve their customers' experience. The advent of VR technology and the ubiquity of mobile devices and free apps provide sound arguments to embrace VR while teaching marketing and preparing business students for future jobs.

Despite its popularity and unquestionable appeal to today's students, little is known about opportunities that VR would offer to marketing educators. From an instructional perspective, VR could potentially simulate a virtual store or a mall environment (Drake-Bridges et al., 2011; Van Kerrebroeck et al., 2017) and affords flexibility in outlets design and atmospherics that could be otherwise difficult to create or manipulate in a real learning environment. Such flexibility offers possibilities to marketing educators to enable illustrating a large variety of concepts, remotely in a simulated environment.

\section{The Pedagogical Novelty of the VR Simulation}

Unlike other conventional instructional methods, VR affords an immersive learning experience that helps students to grasp concepts by experiencing them fully. Indeed, when using VR activities in class, instructors could blend a constructivist approach whereby students create knowledge through 
learning experiences (Sharma et al., 2013) with a behavioral approach whereby students learn by reacting to or observing others' behavior (Bailenson et al., 2008). From this perspective, VR appears to be of greater flexibility in using mixed approaches than other existing instructional methods. Prior empirical studies and meta-analyses have shown that immersion simulations would improve learning outcomes and increase learning session effectiveness to a larger extent than traditional teaching methods (Merchant et al., 2014). When immersed in an interactive VR environment, students become more engaged, and their interest in the material would increase (Parong \& Mayer, 2018).

As VR enables immersion, interaction, and involvement (Pinho et al., 2009), three levels of learnings would result from the current VR simulation, namely, the cognitive, affective and psychomotor learnings. For instance, when immersed in a VR store environment, students could recognize attributes of the shopping environment (i.e., elements of atmospherics), and categorize these into dimensions, while in fact, both tasks of recognizing and categorizing fall under two domains of Bloom's (1956) taxonomy of cognitive learning, respectively, comprehension and analysis domains. This argument draws on elaborative learning (Dunlosky et al., 2013), where learning is informed by examining reasons (e.g., hedonic shopping) and related concepts (e.g., psychological time, flow state) behind the facts (e.g., shopping task), which fosters deep processing of information resulting in better retention of information. From this perspective, VR boosts the process of knowledge construction and makes learning heuristic and highly interactive (Lau \& Lee, 2015), allowing the students' cognition to move from abstract concepts to concrete ones.

Furthermore, when instructed to do shopping in a VR store environment, students would interact with their environment to operate and perform tasks of purchasing. In this vein, students would learn skilled movements that represent one of the learning domains of Harrow (1972) 's taxonomy of psychomotor learning. Doing so would lend support to the practice effect (Dunlosky et al., 2013), where students' performance would improve as a result of repeated task evaluation.

Besides, when involved in the VR simulations, students would experience a set of related concepts such as the flow state, hedonic shopping, and psychological time, which are consistent with the domain of receiving (i.e., awareness) and responding (i.e., reacting to a stimulus) of Krathwohl's (1964) taxonomy of affective learning. In sum, the use of VR simulation would provide instructors with greater flexibility in using mixed approaches (constructivist and behaviorist), while covering various levels and domains of learning (Figure 1).

\section{Integrating VR into Marketing Curriculum}

A primary goal of the marketing curriculum is to prepare students for the professional workforce (Drake-bridges et al., 2011). The call for integrating VR into the marketing curriculum has been echoed in both the business field (see for example, Why Should You Care About Virtual Reality In Marketing? in Forbes, by Clark, 2017) and academia (see for example, Pros and Cons of Virtual Reality in the Classroom in The Chronicle of Higher Education, by Evans, 2018). With the advent of highly immersive VR technology (e.g., VR head-mounted devices, Google Cardboard, Oculus Rift) and the increasing accessibility of VR applications (e.g., free apps on Google Play, App Store), many companies have embraced the creative potential inherent of VR and its applications for marketing purposes, such as educating customers (see for example, Lowe's Wants to Use a VR Holoroom to Teach You Home Improvement in Popular Mechanics by Dhal, 2017), enhancing their shopping experience (see for example, Walmart has acquired a virtual reality startup as part of its tech makeover, in Recode by DelRey, 2018), and setting a better product testing (see for example, VR could take product testing to the beach and beyond in Science and Technology, by Hundborg Koss, 2018). Furthermore, pedagogy research provides mounting evidence that VR could increase students' engagement and enhance learning. The use of VR in classes provides a heuristic and highly interactive learning environment and offers a playful and enjoyable learning experience to students (Lau \& Lee, 2015; Merchant et al., 2014). 


\section{Figure 1. Alignment of VR simulation with learning domains}

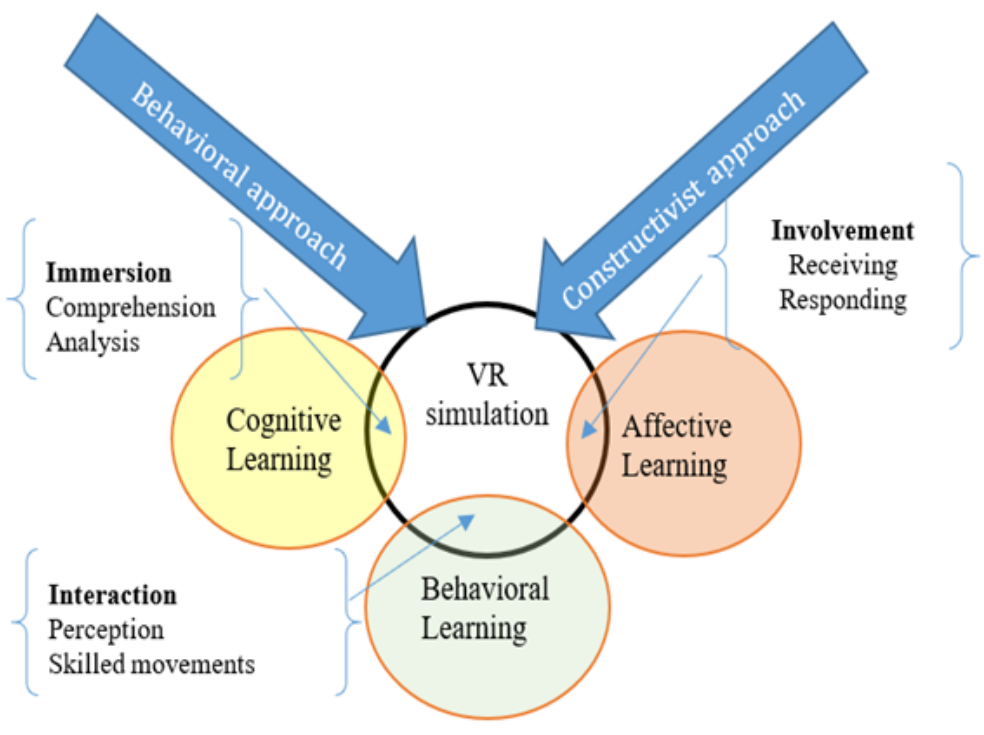

The VR simulation proposed here provides an illustrative example of how this innovation could be used in teaching marketing concepts. Hence, the purpose of this simulation is threefold: to enhance both learning and applications of concepts, to introduce students to the capabilities of VR technology in the marketing world, and to provide students with hands-on experience in using VR for marketing applications. More specifically, the current VR simulation was designed to initiate students to VR and introduce some CB concepts. These concepts are important to know before taking part in the experimentation activity of week \#10 of the marketing research class. The VR simulation helps students (1) to understand the concept of flow state, (2) to comprehend the notion of psychological time (perceived vs. actual time), (3) to know how to manipulate the perception of time, and (4) to differentiate between a high-involvement and a low-involvement purchase.

\section{Description of the VR Simulation}

To participate in the VR simulation, students need to download a free app My3Dstore on their Smartphone and use a VR headset (economic model is available in the market for the cost of \$5). The app simulates a 3D virtual environment that combines a real shopping experience at a retail grocery store with the benefits of online shopping. While visiting a virtual supermarket, where the products and aisles are laid out as if they are in a bricks-and-mortar store, students could move around an aisle, find out the name and price of a product by gazing the product, add a product to the cart, and check the amount to pay by looking at the cart (see Figure 2).

Students would experience a flow state when they become immersed in a shopping activity to the point that they cannot notice anything else. In situations of high involvement, students enter a flow state characterized by a sense of playfulness and a distorted sense of time. The flow state occurs when the temporal duration (i.e., perceived time) of a virtual walk in the store is thought to be relatively shorter than its actual elapsed time. In other words, there is evidence of a flow state when 
Figure 2. Pictures of virtual experience with My2DStore app

Figure 2. Pictures of a Virtual shopping experience with $\underline{\text { My3DStore app }}$
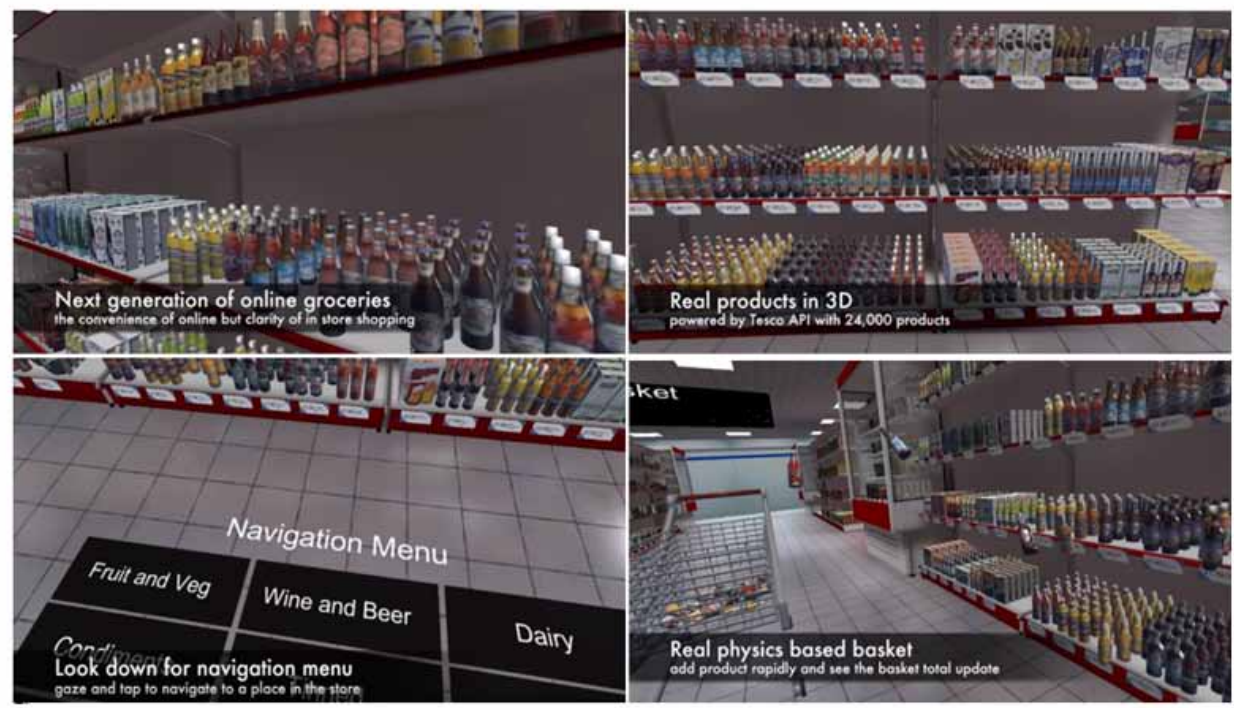

the perceived time (subjective time) is shorter than the actual time (objective time). A snapshot of the VR simulation is presented in Table 1.

To participate in the VR simulation, students need to work in pairs. Students are provided with some materials to read before coming to the class and a booklet of instructions (for full instruction, see Table 2). The VR activity lasts for 75 minutes. The first 10 minutes of class is dedicated to reviewing

Table 1. Snapshot of the VR simulation

\begin{tabular}{|l|l|}
\hline Participants & $\begin{array}{l}\text { Students will work in pairs (i.e., student\#1 will be using the timer, student\#2 } \\
\text { will experience the VR, then they rotate). }\end{array}$ \\
\hline Learning environment & $\begin{array}{l}\text { Classroom+ ONE Laptop (to run a t-test on excel) per group, Smartphones screens } \\
\text { up to } 6 \text { inches), VR Headsets + My3DStore app could be downloaded for free } \\
\text { from this link: https://vrjam.devpost.com/submissions/36811-my3dstore }\end{array}$ \\
\hline Instruction materials & $\begin{array}{l}\text { Reading material: } \\
\text { - Why Should You Care About Virtual Reality In Marketing? in Forbes, by Clark } \\
\text { (2017) } \\
\text { - Textbook Chapter \#10: Buying and Disposing + instructions booklet } \\
\text { - Selected chapters from Human walking in virtual environments, Perception, } \\
\text { Technology, and Applications, by Steinicke et al. (2013) }\end{array}$ \\
\hline Goal & $\begin{array}{l}\text { Estimate a flow state=subjective time (ST)- objective time (OT) } \\
\text { ST: “how long (you think) have you been walking in the VR environment?” } \\
\text { OT: real-time measured with a timer } \\
\text { There is a flow state when ST<OT }\end{array}$ \\
\hline Duration & 75 minutes \\
\hline Key learning concepts & $\begin{array}{l}\text { Flow state, high-involvement purchase, perceived (subjective) time, actual } \\
\text { (objective) time }\end{array}$ \\
\hline
\end{tabular}


Table 2. VR simulation instructions

\begin{tabular}{|c|c|c|c|}
\hline Time slot & Step & Role/material & Instructions \\
\hline Up to $10 \mathrm{~min}$ & Step\#1 & $\begin{array}{l}\text { - Professor } \\
\text { - Instructions booklet \& } \\
\text { PowerPoints } \\
\text { - Selected chapters from } \\
\text { Human walking in virtual } \\
\text { environments, Perception, } \\
\text { Technology, and } \\
\text { Applications, by Steinicke } \\
\text { et al. (2013) }\end{array}$ & $\begin{array}{l}\text { 1. Brief review of key concepts } \\
\text { o Flow state } \\
\text { o High vs. low-involvement } \\
\text { o Psychological time } \\
\text { o Subjective vs. Objective time } \\
\text { 2. Overview of types of walk in a VR space } \\
\text { o Look movement (i.e., gazing) } \\
\text { o Physical movement (i.e., body movement) } \\
\text { o Space movement (i.e., the use of controller) }\end{array}$ \\
\hline Up to $15 \mathrm{~min}$ & Step\#2 & Professor/all students & $\begin{array}{l}\text { 3. Initiation to VR simulations } \\
\text { o } \underline{\text { Go to My3DStore link }} \\
\text { o Download the VR app on your smartphone } \\
\text { o } \text { Open the downloaded VR app } \\
\text { o } \underline{\text { Insert your smartphone into headset }} \\
\text { o } \underline{\text { Hold the headset up to your eyes }} \\
\text { o } \underline{\text { Walk }} \text { and explore the environment }\end{array}$ \\
\hline Up to $15 \mathrm{~min}$ & Step\#3 & Student pairs & 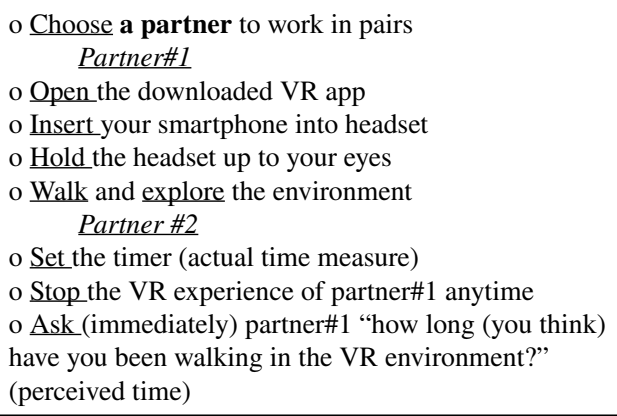 \\
\hline Up to $15 \mathrm{~min}$ & Step\#4 & Student pairs & o Rotate roles (partners\#1 and 2) and Redo \\
\hline Up to $10 \mathrm{~min}$ & Step\#5 & Professor/all pairs & $\begin{array}{l}\text { o Gather data from all pairs } \\
\text { o } \underline{\text { Run a t-test to test for the significance of differences }} \\
\text { between actual time and subjective time }\end{array}$ \\
\hline Up to $10 \mathrm{~min}$ & Step\#6 & Professor/ PowerPoints & $\begin{array}{l}\text { o Link the VR simulation to the course objectives and } \\
\text { learning outcomes. } \\
\text { o Ask students to reflect on their VR experience }\end{array}$ \\
\hline
\end{tabular}

some concepts discussed in class (e.g., high vs. low involvement, flow state, psychological time) and show students how to navigate in a VR space. The next 15 to 20 minutes are used for a trial on how to set up a VR experience and time measurement. Thereafter, students are instructed to set up and run the shopping VR simulation for 30 minutes. The simulation ends with a debrief session to wrap-up. The implementation of the simulation would integrate five steps in addition to the brief and debrief sessions. All steps with time slots and supporting materials and instructions are detailed in Table 2 below.

\section{METHOD}

\section{Participants}

All participants in the current study are marketing students at Kent State University at Stark, who took part in this research for course credit. A total of sixty students have been randomly assigned to one of the two learning conditions: think-pair-share and VR. Hence, two groups of equal size $(n=30)$ 
have participated in each learning condition of the study (think-pair-share vs. VR conditions). This study was reviewed and approved by the Kent State Institutional Review Board, and all students were given informed consent and were aware of their right to withdraw at any time. In the end, no withdrawal was reported as all students have fully participated in the study.

\section{Procedure}

The study was carried out half-way through a 16-week fall and spring semesters. Students from the first group were instructed to read a short article (a text-based resource on psychological time, flow state, and hedonic shopping, created by the professor), then answer a few questions (e.g., What is an objective time versus a subjective time and how you can measure it? Define the flow sate and explain how it correlates with the subjective and objective time?) and share their understanding of concepts with their peers (think-pair-share). At the end of this activity, students completed the short survey. Students from the second group were asked to pair and participate in the VR simulation. Likewise, a survey was administered right after the VR activity to assess their intrinsic motivation and learning effectiveness.

\section{Measures}

The effectiveness of the VR simulation was assessed by comparison to a think-pair-share activity with a short survey assessing students' motivation, self-efficacy, and learning effectiveness - all are dependent variables. Items used in the surveys (see Table 3 ) were adapted from the survey instruments by Lee et al. (2010) and DeNoyelles et al. (2014). All measures are made on a seven-point scale, asking participants to rate the extent to which they might agree or disagree with each item's statement.

\section{ANALYSES AND RESULTS}

Students overwhelmingly reported enjoying the VR simulation with a mean of 6.17 (95\% CI, 6.03-6.30) on a seven-point scale and a small standard deviation (.379). Besides, students have reported higher interest in the topic while using the VR simulation ( $\mathrm{M}=6.37$; std. dev=.547; 95\% CI [6.17-6.56]) as compared to participating in the think-pair-share activity ( $\mathrm{M}=4.43 ;$ std. dev=.504; 95\% CI [4.25-4.61]), Cohen's d=3.65). Overall, students who took part in the VR simulation have reported a better gain in understanding and learning concepts as well as a better learning experience $(\mathrm{M}=5.80 ;$ std. dev=.407; 95\% CI [5.65-5.94]; $\mathrm{M}=5.77 ;$ std. dev=.568; 95\% CI [5.66-5.97]; $\mathrm{M}=5.67 ;$ std. dev=.479; 95\% CI [5.49-5.84]) as compared to those who participated in the think-pair-share activity $(\mathrm{M}=4.63$; std. $d e v=.556 ; 95 \%$ CI [4.43-4.82]; $\mathrm{M}=4.60 ;$ std. $d e v=.498 ; 95 \%$ CI [4.42-4.77]; $\mathrm{M}=4.43 ;$ std. dev=.504; 95\% CI [4.08-4.51]), all Cohen's d are below 3, respectively $(2.40,2.19,2.52)$, suggesting a small to medium effect size. Table 3 summarizes the main descriptive statistics.

Items 1 to 3 were averaged to create a score for perceived teaching effectiveness. Likewise, items 4 and 5 were averaged to create a score for intrinsic motivation, while items 6 and 7 were averaged to calculate a score of self-efficacy. Then a one-way ANOVA was performed to test for differences in intrinsic motivation and learning effectiveness across the VR simulation and think-pair-share activity scenarios. ANOVA results show significant differences between the two scenarios in terms of intrinsic motivation $(F(1,58)=230.41 ; \mathrm{p}=.000<.05)$ and perceived learning effectiveness $(F(1,58)=319.39$; $\mathrm{p}=.000<.05)$; the use of VR simulation would result in a higher intrinsic motivation $(\mathrm{M}=6.26)$ and a better learning outcome $(M=5.74)$ as compared to the use of think-pair-share activity $(M=4.36$; $\mathrm{M}=4.55$ ). However, the use of VR may not lead to a better ability to apply concepts as compared to the use of think-pair-share activity $(F(1,58)=.105 ; \mathrm{p}=.747>.05 ; \mathrm{M}=3.25, \mathrm{M}=3.28)$. 
Table 3. Descriptive statistics of learning effectiveness of VR simulation as compared to think-pair-share activity

\begin{tabular}{|c|c|c|c|}
\hline Items & $\mathbf{N}$ & Mean & Std dev \\
\hline $\begin{array}{l}\text { 1. The VR simulation [think-pair-share activity] helped me to gain a } \\
\text { good understanding of basic concepts. }\end{array}$ & $30(30)$ & $5.80(4.63)$ & $.407(.556)$ \\
\hline $\begin{array}{l}\text { 2. The VR simulation [think-pair-share activity] helped me to learn } \\
\text { concepts. }\end{array}$ & $30(30)$ & $5.77(4.60)$ & $.568(.498)$ \\
\hline $\begin{array}{l}\text { 3. The VR simulation [think-pair-share activity] enhanced my learning } \\
\text { experience. }\end{array}$ & $30(30)$ & $5.67(4.43)$ & $.479(.504)$ \\
\hline 4. I enjoyed working on the VR simulation [think-pair-share activity]. & $30(30)$ & $6.17(4.30)$ & $.379(.596)$ \\
\hline $\begin{array}{l}\text { 5. The VR simulation [think-pair-share activity] increased my interest } \\
\text { in the topic. }\end{array}$ & $30(30)$ & $6.37(4.43)$ & $.556(.504)$ \\
\hline $\begin{array}{l}\text { 6. I can apply what I learned from the VR simulation [think-pair-share } \\
\text { activity] in a real context. }\end{array}$ & $30(30)$ & $3.17(3.33)$ & $.531(.547)$ \\
\hline $\begin{array}{l}\text { 7. I believe I have the ability to apply the concepts I learned from the } \\
\text { VR simulation [think-pair-share activity]. }\end{array}$ & $30(30)$ & $3.33(3.28)$ & $.547(.568)$ \\
\hline
\end{tabular}

\section{DISCUSSION}

This study aimed to assess the learning effectiveness and students' intrinsic motivation when using smartphone-based VR app in teaching marketing concepts. To this end, a comparison was made between two independent groups of students. Students from the first group were tasked to read a short article and answer a few questions and share their understanding of concepts with their peers (think-pair-share activity). Students from the second group were asked to pair and participate in the VR simulation. A survey was administered to participants in each group to collect data and assess their intrinsic motivation, self-efficacy, and learning effectiveness. Results show that students who took part in the VR simulation have reported a better gain in understanding and learning concepts and have reported a better learning experience as compared to those who participated in the thinkpair-share activity.

These findings are consistent with prior studies suggesting that VR immersion would lead to better retention of information and higher learning effectiveness (Lee et al., 2010; Zhang et al., 2017). Besides, the results from this study show that VR could spark student's motivation to learn. In contrast with students who took part in the think-pair-share activity, those who have experienced the VR simulation showed more interest in learning about the subject. Clearly, the use of VR simulation could prime student's interest more than any conventional learning activity, which is typically the case for millennials who grew up with immersive technology, in particular VR (Polger \& Sheidlower, 2017). In fact, a major perspective about motivation is based on interest theory (Schiefele, 1991). According to the theory, students will be intrinsically motivated if they find fun and playfulness in what they learn (Garris et al., 2002). Hence, motivation and learning go hand in hand. This lends support to prior research pointing towards student motivation to play a key role in learning concepts; those who are more motivated to use VR are more likely to engage in the lesson and put more effort into understanding the material (Lund \& Wang, 2019).

However, results from the current study show that the use of VR may not lead to a better ability to apply concepts as compared to the think-pair-share activity. This finding contradicts prior studies describing VR as a tool of self-efficacy empowerment (Nissim \& Weissblueth, 2017). A plausible explanation of why self-efficacy (i.e., the person's judgments of his ability to perform a given task) was higher in the think-pair-share activity as compared to the VR simulation could be the complexity of the self-efficacy process itself. In this vein, Schunk (1989) describes the process of self-efficacy as a feedback loop. First, the student has his beliefs about his self-efficacy (i.e., I'm good at this). This 
belief then affects the student's task engagement (i.e., I will try hard). After the task, the student receives feedback (i.e., I did well on the task) and receives efficacy cues from the feedback (i.e., the instructor thinks I'm good at this). Finally, this aptitude feedback reshapes the student's self-efficacy. Applying this reasoning to the current study, it is possible that students found more value in the feedback they received on the think-pair-share activity, from their peers and the instructor, by comparison to the feedback they received from the instructor on the VR simulation. In this regard, to get a better gain on self-efficacy in the VR simulation, it is recommended to incorporate a feedback system that tracks the progress in executing tasks into the VR environment. Overall, this study provides an illustrative example of how VR could be used to teach CB concepts and increase students' motivation to learn about marketing.

Furthermore, the VR simulation could also be integrated into the teaching of other business classes, such as marketing research and retailing. For instance, the current simulation could be extended to illustrate some stages in the consumer buying decision process (e.g., information search, evaluation of alternatives), the Affective-Behavioral and Cognitive model of attitudes, and planned vs. unplanned purchasing, to nominate a few. Likewise, the VR activity could be used in retailing management class to illustrate and experience concepts related to atmospherics (e.g., the store layout, and display design, fixtures) and merchandising. Furthermore, VR simulation could be used to teach students how to set an experiment properly, experimental design, randomization, control, internal vs. external validity, and more. In sum, VR simulations provide a flexible and adaptable teaching tool for many marketing classes.

\section{LIMITATIONS AND FUTURE DIRECTIONS}

The current research highlights some merit in incorporating VR into the teaching of marketing concepts. The study comes with some limitations. First, the sample size for this study is limited to 30 students in each group. A larger sample of students would increase the validity of the results. Second, the measures used in this research are subjective measures that capture students' perception of what they learned and their ability to apply concepts. These measures should be supplemented with direct measures such as quizzes to assess VR learning outcomes objectively.

While VR simulation could boost students' motivation to learn and the learning effectiveness, it may not appeal to all students. For instance, students who have prior experience with VR as applied to video games and entertainment would take more advantage of VR simulations as compared to those who may not be familiar with VR applications. In fact, the use of VR simulation may not fit all students learning styles. Common sense suggests that active learners (those who learn by doing and participating) and sensory learners (learn by experimentation) would take more advantage of VR simulations as compared to passive and verbal learners (Bell \& Fogler, 1997).

Besides, setting up the VR simulation in class comes with some challenges. For instance, some free apps could not simulate a highly immersive environment (i.e., due to a low-resolution quality of the simulated environment) and therefore would significantly limit the possibilities of instructing students to perform tasks in the VR environment. Furthermore, some apps may not be compatible with all types of smartphones. For example, some apps could be installed only on iPhone or Android with screens up to 6 inches). Moreover, the use of VR in classrooms with limited space would require VR headsets equipped with remote control, that would facilitate physical movements in a space while navigating in the virtual environment and would help to avoid in-class traffic. However, the cost of acquiring VR headsets with remote controls is higher than conventional VR headsets.

Noteworthy, from an instructional perspective, the use of VR cannot replace lectures, textbooks, or laboratories. However, VR could be used to supplement traditional educational methods. For example, VR could be offered as an available resource for students who did not fully grasp the material discussed in class or from the text. Nevertheless, the instructors should carefully consider the 
International Journal of Innovative Teaching and Learning in Higher Education

Volume $2 \cdot$ Issue $1 \cdot$ January-March 2021

trade-offs between the simulation realism and learning performance. In doing so, instructors should plan out the simulation carefully while aligning it to the learning objectives and expected outcomes. 


\section{REFERENCES}

Amin, A., Gromala, D., Tong, X., \& Shaw, C. (2016, July). Immersion in cardboard VR compared to a traditional head-mounted display. In International Conference on Virtual, Augmented and Mixed Reality (pp. 269-276). Toronto, Canada: Springer. doi:10.1007/978-3-319-39907-2_25

Bailenson, J. N., Yee, N., Blascovich, J., Beall, A. C., Lundblad, N., \& Jin, M. (2008). The use of immersive virtual reality in the learning sciences: Digital transformations of teachers, students, and social context. Journal of the Learning Sciences, 17(1), 102-141. doi:10.1080/10508400701793141

Belei, N., Noteborn, G., \& De Ruyter, K. (2011). It's a brand-new world: Teaching brand management in virtual environments. Journal of Brand Management, 18(8), 611-623. doi:10.1057/bm.2011.6

Bell, J. T., \& Fogler, H. S. (1997). Ten steps to developing virtual reality applications for engineering education. In Proceedings of the American Society for Engineering Education Annual Conference (pp. 2109-2136). Washington, DC: ASEE. doi:10.18260/1-2--6831

Bloom, B. S. (1956). Taxonomy of educational objectives: The classification of educational goals: Cognitive Domain. Longman.

Bridges, E. (2020). The undergraduate marketing research course: Two decades of change. Journal of Marketing Education. Advance online publication. doi:10.1177/0273475320960501

Business Insider. (2018, March 4). Here's what happens to your body when you've been in virtual reality for too long. https://www.businessinsider.com/virtual-reality-vr-side-effects-2018-3

Carter, E. V. (2002). Cognitive minds and connected markets: A computer-based consumer behavior course module for the digital future. Marketing Education Review, 12(3), 35-45. doi:10.1080/10528008.2002.11488798

Chen, Y. L. (2016). The effects of virtual reality learning environment on student cognitive and linguistic development. The Asia-Pacific Education Researcher, 25(4), 637-646. doi:10.1007/s40299-016-0293-2

Choi, D. H., Dailey-Hebert, A., \& Estes, J. S. (Eds.). (2016). Emerging tools and applications of virtual reality in education. Information Science Reference. doi:10.4018/978-1-4666-9837-6

Clark. (2017, October 2). Why should you care about virtual reality in marketing? Forbes. https:/www.forbes. com/sites/forbesagencycouncil/2017/10/02/why-should-you-care-about-virtual-reality-in-marketing/

DelRey, J. (2018, February 6). Walmart has acquired a virtual reality startup as part of its tech makeover. Recode. https://www.recode.net/2018/2/6/16977006/walmart-vr-virtual-reality-spatialand-store-no-8

DeNoyelles, A., Hornik, S. R., \& Johnson, R. D. (2014). Exploring the dimensions of self-efficacy in virtual world learning: Environment, task, and content. Journal of Online Learning and Teaching, 10(2), $255-271$.

Dhal. (2017, March 7). Lowe's wants to use a VR holoroom to teach you home improvement. Popular Mechanics. https://www.popularmechanics.com/technology/gear/a25563/lowes-holoroom-how-to-diy/

Dietrich, T., Rundle-Thiele, S., Kubacki, K., Durl, J., Gullo, M. J., Arli, D., \& Connor, J. P. (2019). Virtual reality in social marketing: A process evaluation. Marketing Intelligence \& Planning, 37(7), 806-820. doi:10.1108/ MIP-11-2018-0537

Drake-Bridges, E., Strelzoff, A., \& Sulbaran, T. (2011). Teaching marketing through a micro-economy in virtual reality. Journal of Marketing Education, 33(3), 295-311. doi:10.1177/0273475311420236

Dunlosky, J., Rawson, K. A., Marsh, E. J., Nathan, M. J., \& Willingham, D. T. (2013). Improving students' learning with effective learning techniques: Promising directions from cognitive and educational psychology. Psychological Science in the Public Interest, 14(1), 4-58. doi:10.1177/1529100612453266 PMID:26173288

Evans. (2018, April 8). Pros and cons of virtual reality in the classroom. The Chronicle of Higher Education. https://www.chronicle.com/article/ProsCons-of-Virtual/243016

Garris, R., Ahlers, R., \& Driskell, J. E. (2002). Games, motivation, and learning: A research and practice model. Simulation \& Gaming, 33(4), 441-467. doi:10.1177/1046878102238607 
Harrow, A. J. (1972). A taxonomy of the psychomotor domain: A guide for developing behavioral objectives. Longman.

Hartman, C. L., \& Braunstein, L. A. (1998). A picture is worth a thousand words: Using photography to teach self-concept and introduce students to consumer behavior. Journal of Marketing Education, 20(3), $236-243$. doi:10.1177/027347539802000307

Hassan, A., \& Jung, T. (2018). Augmented reality as an emerging application in tourism marketing education. In Virtual and Augmented Reality: Concepts, Methodologies, Tools, and Applications (pp. 1702-1720). IGI Global. doi:10.4018/978-1-5225-5469-1.ch080

Hundborg, K. L. (2018, March 15). VR could take product testing to the beach and beyond. Futurity. https:// www.futurity.org/virtual-reality-consumer-testing-1703882/

Jensen, L., \& Konradsen, F. (2018). A review of the use of virtual reality head-mounted displays in education and training. Education and Information Technologies, 23(4), 1515-1529. doi:10.1007/s10639-017-9676-0

Krathwohl, D. R., Bloom, B. S., \& Masia, B. B. (1964). Taxonomy of educational objectives, handbook II: Affective domain. David McKay Company.

Lau, K. W., \& Lee, P. Y. (2015). The use of virtual reality for creating unusual environmental stimulation to motivate students to explore creative ideas. Interactive Learning Environments, 23(1), 3-18. doi:10.1080/104 94820.2012 .745426

Lawson, T. J. (1995). Active-learning exercises for consumer behavior courses. Teaching of Psychology, 22(3), 200-202. doi:10.1207/s15328023top2203_12

Lee, E. A. L., Wong, K. W., \& Fung, C. C. (2010). How does desktop virtual reality enhance learning outcomes? A structural equation modeling approach. Computers \& Education, 55(4), 1424-1442. doi:10.1016/j. compedu.2010.06.006

Lincoln, D. J. (2016). The undergraduate consumer behavior course: Current status and pedagogies. In Proceedings of the 1979 Academy of Marketing Science (AMS) Annual Conference (pp. 161-165). New York, NY: Springer. doi:10.1007/978-3-319-16934-7_39

Lund, B. D., \& Wang, T. (2019). Effect of virtual reality on learning motivation and academic performance: What value may VR have for library instruction? Kansas Library Association College and University Libraries Section Proceedings, 9(1), 4. doi:10.4148/2160-942X.1073

Mandal, S. (2013). Brief introduction of virtual reality \& its challenges. International Journal of Scientific and Engineering Research, 4(4), 304-309.

Mangold, K. (2007). Educating a new generation: Teaching baby boomer faculty about millennial students. Nurse Educator, 32(1), 21-23. doi:10.1097/00006223-200701000-00007 PMID:17220763

Merchant, Z., Goetz, E. T., Cifuentes, L., Keeney-Kennicutt, W., \& Davis, T. J. (2014). Effectiveness of virtual reality-based instruction on students' learning outcomes in K-12 and higher education: A meta-analysis. Computers \& Education, 70, 29-40. doi:10.1016/j.compedu.2013.07.033

Morgan, F. N., \& McCabe, D. B. (2012). Learning why we buy: An experiential project for the consumer behavior course. Journal of Marketing Education, 34(2), 140-155. doi:10.1177/0273475312450387

Nissim, Y., \& Weissblueth, E. (2017). Virtual reality (VR) as a source for self-efficacy in teacher training. International Education Studies, 10(8), 52-59. doi:10.5539/ies.v10n8p52

Pantelidis, V. S. (2010). Reasons to use virtual reality in education and training courses and a model to determine when to use virtual reality. Themes in Science and Technology Education, 2(1-2), 59-70.

Pinho, M. S., Bawman, D. A., \& Freitas, C. (2009). Cooperative object manipulation in collaborative virtual environments. Journal of the Brazilian Computer Society, 14(2), 54-67. doi:10.1590/S0104-65002008000200005

Polger, M. A., \& Sheidlower, S. (2017). Engaging diverse learners: Teaching strategies for academic librarians. ABC-CLIO. 
Schiefele, U. (1991). Interest, learning, and motivation. Educational Psychologist, 26(3), 299-323. doi:10.1207/ s15326985ep2603\&4_5

Schunk, D. H. (1989). Self-efficacy and achievement behaviors. Educational Psychology Review, 1(3), 173-208. doi:10.1007/BF01320134

Sharma, S., Agada, R., \& Ruffin, J. (2013). Virtual reality classroom as a constructivist approach. In Proceedings of the 2013 IEEE Southeastcon (pp. 1-5). Jacksonville, FL: IEEE. doi:10.1109/SECON.2013.6567441

Smith, S., \& Fisher, D. (2006). You can observe a lot just by watching: Using videography in a retail setting to teach observational research methods. Marketing Education Review, 16(1), 75-78. doi:10.1080/10528008.20 06.11488942

Sojka, J. Z., \& Fish, M. S. (2008). Brief in-class role plays: An experiential teaching tool targeted to generation Y students. Marketing Education Review, 18(1), 25-31. doi:10.1080/10528008.2008.11489021

Steinicke, F., Visell, Y., Campos, J., \& Lécuyer, A. (2013). Human walking in virtual environments. Springer. doi:10.1007/978-1-4419-8432-6

Titus, P. A., \& Petroshius, S. M. (1993). Bringing consumer behavior to the workbench: An experiential approach. Journal of Marketing Education, 15(1), 20-30. doi:10.1177/027347539301500104

Toshniwal, R., \& Dastidar, K. G. (2014). Virtual reality: The future interface of technology. International Journal of Computer Science and Information Technologies, 5(6), 7032-7034.

Van Kerrebroeck, H., Brengman, M., \& Willems, K. (2017). Escaping the crowd: An experimental study on the impact of a virtual reality experience in a shopping mall. Computers in Human Behavior, 77, 437-450. doi:10.1016/j.chb.2017.07.019

Zhang, X., Jiang, S., Ordóñez de Pablos, P., Lytras, M. D., \& Sun, Y. (2017). How virtual reality affects perceived learning effectiveness: A task-technology fit perspective. Behaviour \& Information Technology, 36(5), 548-556. doi:10.1080/0144929X.2016.1268647

Haithem Zourrig $(P h D)$ is an associate professor of marketing at Kent State University at Stark. His pedagogical research interests include the use of virtual and augmented realities in business education and simulation games. Dr. Zourrig received many Best Paper Awards from the Society for Marketing Advances (SMA) and the American Society of Business and Behavioral Sciences (ASBBS). He also received the McGraw-Hill Education Distinguished Award from the Federation of Business Disciplines (FBD) and the 2018 AxcessCapon Teaching Innovation Award from the Association of Collegiate Marketing Educators (ACME). 